\title{
Growth Inhibition of Enteric Pathogens by Zinc Sulfate: An in vitro Study
}

\author{
Julius E. Surjawidjaja ${ }^{a}$ Adi Hidayat ${ }^{b}$ Murad Lesmana ${ }^{a}$ \\ Departments of a Microbiology and bPublic Health, Medical Faculty, Trisakti University, Jakarta, Indonesia
}

\author{
Key Words \\ Growth inhibition - Enteric pathogen · Zinc
}

\begin{abstract}
Objective: To determine the inhibition effect of zinc sulfate on isolates of enteric bacteria. Materials and Methods: Mueller-Hinton agar containing different concentrations of zinc sulfate was prepared. Isolates used in this study were obtained from local clinics. They were Salmonella typhi, Salmonella groups A, B, C, D and E, Escherichia coli, Enterobacter, Shigella and Vibrio cholerae. Overnight cultures of test organisms in brain-heart infusion broth were adjusted to 0.5 McFarland standard turbidity by adding normal saline with $1 \mu \mathrm{l}$ of each adjusted broth culture inoculated onto zinc sulfate agar plates. The plates were incubated for $18-20 \mathrm{~h}$ at $37^{\circ} \mathrm{C}$. The inhibition concentration was recorded as the lowest concentration of zinc sulfate that completely inhibited growth. Results: All enteric pathogens tested were inhibited by zinc sulfate. Of the isolates, S. typhi was most sensitive since $20 \%$ of the strains were inhibited by zinc sulfate of $0.8 \mathrm{mg} / \mathrm{ml}$. Salmonella paratyphi A was inhibited at $1.2 \mathrm{mg} / \mathrm{ml}$. Other Salmonella spp. were inhibited at concentrations between 1.4 and $2.0 \mathrm{mg} / \mathrm{ml}$. V. cholerae $\mathrm{O} 1$ and Shigella flexneri demonstrated a similar pattern of inhibition as $S$. paratyphi A. A higher concentration of zinc sulfate $(1.6 \mathrm{mg} / \mathrm{ml})$ was required to completely
\end{abstract}

\section{KARGER}

Fax +4161306 1234

E-Mail karger@karger.ch

www. karger.com

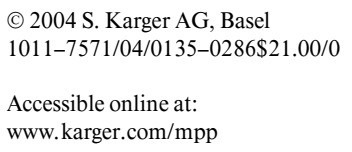

inhibit Shigella sonnei. Conclusion: The findings indicate that zinc sulfate has an antimicrobial effect on enteric pathogens and may contribute to the treatment of diarrhea.

Copyright $@ 2004$ S. Karger AG, Basel

\section{Introduction}

Infectious diarrheal diseases are a leading cause of morbidity and mortality worldwide. Between 1978 and 1987, global mortality due to diarrhea among children less than 5 years of age was estimated at 3.3 million deaths per year, with a case fatality rate of $0.3 \%$ [1]. In Indonesia, similar mortality rates associated with diarrheal disease (1-8 per 1,000 children less than 5 years old), with the highest death rate among infants ( $<12$ months) have been observed [2]. Household surveillance conducted by the Indonesian Ministry of Health in 1995 [3] showed that approximately $15 \%$ of deaths among infants and $25 \%$ among children between 1 and 4 years old were caused by severe diarrhea. Although the use of oral rehydration solution has been successful and substantial global progress has been made in reducing mortality due to diarrhea, current rates of morbidity as a result of infectious diarrhea remain a major public health problem [4]. Studies on zinc supplementation in children with acute diarrhea have been shown to be effective in reducing the duration of 
diarrhea and preventing persistent diarrhea [5-7]. Results of pooled analyses showed that children taking zinc supplements had a $15 \%$ lower probability of continued symptoms on a given day during an episode of acute diarrhea [6]. Although results from several studies support the beneficial effects of zinc in preventing prolonged diarrhea, the mechanism of such action is not completely understood $[8,9]$. It is thought that zinc enhances the recovery and regeneration of impaired intestinal epithelial cells caused by diarrhea. Effects of zinc deficiency on cellular immunity response are well known, and zinc supplementation has been shown to improve the symptoms of lymphoid atrophy and increase the number of $\mathrm{T}$ and $\mathrm{B}$ lymphocytes [10]. However, the effectiveness of zinc administration should be appropriately investigated before it is recommended routinely as an adjunct therapy for acute childhood diarrhea.

Therefore, the aim of this study was to investigate the inhibition effects of zinc on enteric bacterial isolates.

\section{Methods and Materials}

\section{Zinc Sulfate Agar}

A stock solution of zinc sulfate was prepared by dissolving $0.2 \mathrm{~g}$ of $\mathrm{ZnSO}_{4} \cdot 7 \mathrm{H}_{2} \mathrm{O}$ in $10 \mathrm{ml}$ of distilled water to obtain a concentration of $20 \mathrm{mg} / \mathrm{ml}$. The solution was sterilized by filtration, using a Millipore filter (Millipore Co., Bedford, Mass., USA). To prepare agar media with various concentrations of zinc sulfate (zinc sulfate agar; ZSA), different volumes of zinc sulfate stock solution $(20 \mathrm{mg} / \mathrm{ml})$ between 0.2 and $2.0 \mathrm{ml}$ were added into the tubes containing $20 \mathrm{ml}$ melted $\left(50^{\circ} \mathrm{C}\right)$ Mueller-Hinton agar as described in table 1. The MuellerHinton ZSA was poured into a sterile Petri plate and set at room temperature.

\section{Bacterial Cultures}

Isolates of enteric pathogens used in this study were wild-type strains obtained from local clinics in Jakarta, Indonesia, including Salmonella typhi, Salmonella paratyphi A, Salmonella groups A, B, C, D and E, Escherichia coli, Enterobacter, Shigella and Vibrio cholerae O1. Cultures were maintained in tryptic soy broth with $20 \%$ glycerol and stored at $-70^{\circ} \mathrm{C}$. Before testing, cultures were thawed and inoculated onto blood agar medium, incubated at $37^{\circ} \mathrm{C}$ for 18 $20 \mathrm{~h}$. Colonies were picked and identified by biochemical reactions for confirmation of purity. Pure culture was transferred into $5 \mathrm{ml}$ of brain-heart infusion broth and incubated at $37^{\circ} \mathrm{C}$ overnight.

\section{Inoculation of ZSA}

Overnight bacterial cultures in brain-heart infusion broth were adjusted to $0.5 \mathrm{McF}$ arland standard turbidity by adding normal $(0.85 \%)$ saline. The ZSA was inoculated using an inoculum replicating apparatus transferring 32 inocula per microtiter plate (Corning Costar, Corning, N.Y., USA). A 10- $\mu 1$ sample of broth culture was dispensed into the well of a microtiter plate, and the inoculum replicating apparatus was used to transfer $1 \mu 1$ of the broth culture to ZSA. The broth cultures were also inoculated onto plain (no zinc sulfate)
Table 1. The addition of zinc sulfate $\left(\mathrm{ZnSO}_{4} \cdot 7 \mathrm{H}_{2} \mathrm{O}, 20 \mathrm{mg} / \mathrm{ml}\right)$ to Mueller-Hinton agar to make ZSA with various concentrations of zinc sulfate

\begin{tabular}{llll}
\hline $\begin{array}{l}\text { Medium } \\
\text { No. }\end{array}$ & $\begin{array}{l}\text { Volume of zinc } \\
\text { sulfate added, } \mathrm{ml}\end{array}$ & $\begin{array}{l}\text { Mueller Hinton } \\
\text { volume, } \mathrm{ml}\end{array}$ & $\begin{array}{l}\text { Concentration in ZSA } \\
\text { of zinc sulfate, } \mathrm{mg} / \mathrm{ml}\end{array}$ \\
\hline 1 & 0 & 20 & 0 \\
2 & 0.2 & 19.8 & 0.2 \\
3 & 0.4 & 19.6 & 0.4 \\
4 & 0.6 & 19.4 & 0.6 \\
5 & 0.8 & 19.2 & 0.8 \\
6 & 1 & 19 & 1 \\
7 & 1.2 & 18.8 & 1.2 \\
8 & 1.4 & 18.6 & 1.4 \\
9 & 1.6 & 18.4 & 1.6 \\
10 & 1.8 & 18.2 & 1.8 \\
11 & 2 & 18 & 2 \\
\hline
\end{tabular}

Mueller-Hinton agar as a control. Plates were incubated for 18-20 h at $37^{\circ} \mathrm{C}$.

\section{Inhibition Concentration}

The inhibition concentration was recorded as the lowest concentration of zinc sulfate that completely inhibited growth, disregarding a single colony or faint haze caused by the inoculum.

\section{Results}

The results of enteric pathogen inhibition by zinc sulfate are shown in table 2 . Twenty percent of $S$. typhi were inhibited by zinc sulfate at a concentration of $0.8 \mathrm{mg} / \mathrm{ml}$, while other isolates except Salmonella group C were beginning to show inhibition at concentrations of $\geq 1.2$ $\mathrm{mg} / \mathrm{ml}$. All $S$. typhi isolates were completely inhibited at $1.6 \mathrm{mg} / \mathrm{ml}$. All $S$. paratyphi A failed to grow at a concentration of $1.2 \mathrm{mg} / \mathrm{ml}$. Half of Salmonella group B were inhibited at $1.2 \mathrm{mg} / \mathrm{ml}$ and did not grow at concentrations $\geq 1.4 \mathrm{mg} / \mathrm{ml}$. Fifty percent and $80 \%$ of Salmonella group $\mathrm{C}$ were inhibited at concentrations of 1.4 and $1.6 \mathrm{mg} / \mathrm{ml}$, respectively, and were totally inhibited at $1.8 \mathrm{mg} / \mathrm{ml}$. Salmonella group E did not grow at $2.0 \mathrm{mg} / \mathrm{ml}$.

Complete inhibition was shown at $1.2 \mathrm{mg} / \mathrm{ml}$ for isolates of $V$. cholerae $\mathrm{O} 1$ and Shigella flexneri, whereas Shigella sonnei was inhibited at $1.6 \mathrm{mg} / \mathrm{ml}$. Enterobacter aerogenes and Enterobacter cloacae were inhibited at 1.4 and $1.8 \mathrm{mg} / \mathrm{ml}$, respectively, while $E$. coli was inhibited at $1.6 \mathrm{mg} / \mathrm{ml}$. All enteric pathogens tested, except for $40 \%$ of Salmonella group E isolates, were completely inhibited at zinc sulfate concentrations $\geq 1.8 \mathrm{mg} / \mathrm{ml}$. 
Table 2. Inhibition concentration of zinc sulfate $(0-2 \mathrm{mg} / \mathrm{ml})$ for enteric pathogens

\begin{tabular}{|c|c|c|c|c|c|c|c|c|c|c|c|c|}
\hline \multirow[t]{2}{*}{ Organism } & \multirow[t]{2}{*}{$\begin{array}{l}\text { Number } \\
\text { tested }\end{array}$} & \multicolumn{11}{|c|}{$\begin{array}{l}\text { Cumulative percentages of isolates inhibited by the following } \\
\text { concentrations of zinc sulfate }\end{array}$} \\
\hline & & 0 & 0.2 & 0.4 & 0.6 & 0.8 & 1 & 1.2 & 1.4 & 1.6 & 1.8 & 2 \\
\hline Shigella flexneri & 10 & 0 & 0 & 0 & 0 & 0 & 30 & 100 & & & & \\
\hline Shigella sonnei & 10 & 0 & 0 & 0 & 0 & 0 & 10 & 20 & 60 & 100 & & \\
\hline Salmonella paratyphi A & 10 & 0 & 0 & 0 & 0 & 0 & 40 & 100 & & & & \\
\hline Salmonella group B & 10 & 0 & 0 & 0 & 0 & 0 & 10 & 50 & 100 & & & \\
\hline Salmonella group C & 10 & 0 & 0 & 0 & 0 & 0 & 0 & 0 & 50 & 80 & 100 & \\
\hline Salmonella group D & 10 & 0 & 0 & 0 & 0 & 0 & 50 & 70 & 90 & 100 & & \\
\hline Salmonella group E & 10 & 0 & 0 & 0 & 0 & 0 & 30 & 60 & 60 & 60 & 60 & 100 \\
\hline Salmonella typhi & 10 & 0 & 0 & 0 & 0 & 20 & 70 & 80 & 90 & 100 & & \\
\hline Enterobacter aerogenes & 10 & 0 & 0 & 0 & 0 & 0 & 40 & 40 & 100 & & & \\
\hline Enterobacter cloacae & 10 & 0 & 0 & 0 & 0 & 0 & 50 & 80 & 80 & 100 & & \\
\hline Escherichia coli & 10 & 0 & 0 & 0 & 0 & 0 & 30 & 80 & 80 & 100 & & \\
\hline Vibrio cholerae $\mathrm{O} 1$ & 10 & 0 & 0 & 0 & 0 & 0 & 20 & 100 & & & & \\
\hline Vibrio cholerae non-O1 & 10 & 0 & 0 & 0 & 0 & 0 & 50 & 100 & & & & \\
\hline
\end{tabular}

\section{Discussion}

Zinc supplementation has been associated with clinical reduction in duration and severity of diarrhea in infants and young children [5-7]. It also reduced the risk of continued diarrhea, measured as decreased frequency of prolonged diarrhea and the number of days with watery stools. The probable mechanisms for the antidiarrheal effect of zinc sulfate supplementation have included improved absorption of water and electrolytes by the intestine, regeneration of intestinal epithelium and the restoration of its function, increased levels of enterocyte brush border enzymes and enhanced immunological mechanisms for clearance of infection [8-10].

Our in vitro study shows that zinc sulfate at concentrations between 1.2 and $1.8 \mathrm{mg} / \mathrm{ml}$ inhibited growth in enteric pathogens commonly associated with diarrheal disease. Zinc sulfate in the form of $\mathrm{ZnSO}_{4} \cdot 7 \mathrm{H}_{2} \mathrm{O}$ was used in this study because this agent has been widely administered for supplementation in diarrheal disease and has proven to be effective in reducing the frequency and severity of diarrhea episodes. Except for $40 \%$ of Salmonella group $\mathrm{E}$ which was inhibited by zinc sulfate at a concentration of $1.8 \mathrm{mg} / \mathrm{ml}$, most other enteric pathogens were readily inhibited at concentrations between 1.4 and $1.6 \mathrm{mg} / \mathrm{ml}$ (table 2). The dosage of zinc supplementation used in India as reported by Sazawal et al. [11] was $20 \mathrm{mg}$ daily which is equal to $88 \mathrm{mg}$ zinc sulfate $\left(\mathrm{ZnSO}_{4} \cdot 7 \mathrm{H}_{2} \mathrm{O}\right)$. Taking into account that only $5-26 \%$ of zinc sulfate will be absorbed [12], 74-95\% or $65.1-83.6 \mathrm{mg}$ of the initial dose $(88 \mathrm{mg})$ given to the patients will actually remain in the gut unabsorbed. This amount will be distributed in the entire gut, and some factors, namely relative gut motility, water intake and retention as well as the number of zinc tablets taken by patients, may alter the relative concentration of the unabsorbed zinc sulfate and may cause the local concentration of zinc sulfate in a given site of the gut to be much lower. However, this small amount of zinc sulfate may still be effective to inhibit the enteric pathogens. Thus, zinc may not only have a physiological therapeutic effect, but an antimicrobial one as well, suggesting that the improvement in severity and the decreased risk of prolonged diarrhea attacks may be due to these dual effects of zinc sulfate.

\section{Conclusion}

Zinc has an antimicrobial effect on enteric pathogens and may contribute to the treatment of acute diarrhea.

\section{Acknowledgement}

We thank the staff of the Department of Microbiology, Medical Faculty, Trisakti University, for the laboratory work. We are grateful to Dr. Michael Bangs for critically reviewing the manuscript. 


\section{References}

1 Bern C, Martines J, de Zoysa I, Glass RI: The magnitude of the global problem of diarrhoeal disease: A ten-year update. Bull World Health Organ 1992;70:705-714.

2 Sunoto: Diarrhoeal problems and infants and child mortality in Indonesia. Paediatr Indones 1985;86:71-86.

3 Ministry of Health, Republic of Indonesia: Household Health Survey 1995. Jakarta, Ministry of Health, Republic of Indonesia, 1996.

4 Taylor DN, Echeverria P: Diarrheal disease: Current concepts and future challenges: Molecular biological approaches to the epidemiology of diarrhoeal diseases in developing countries Trans R Soc Trop Med Hyg 1993;87(suppl 3):3-5.
5 Hidayat A, Achadi A, Sunoto, Soedarmo SP: The effect of zinc sulfate supplementation in children under three years of age with acute diarrhea in Indonesia. Med J Indones 1998;7: 237-241

6 Bhutta ZA, Bird SM, Black RE, Brown $\mathrm{KH}$, Gardner JM, Hidayat A, Khatun F, Martorell R, Ninh NX, Penny ME, Rosado JL, Roy SK, Ruel SK, Sazawal S, Shankar A: Therapeutic effects of oral zinc in acute and persistent diarrhea in children in developing countries: Pooled analyses of randomized controlled trials. Am J Clin Nutr 2000;72:1516-1522.

7 Strand TA, Chandyo RK, Bahl R, Sharma PR, Adhikari RK, Bhandari N, Ulvik RJ, Molbak K, Bhan MK, Sommerfelt H: Effectiveness and efficacy of zinc for treatment of acute diarrhea in young children. Pediatrics 2002;109:898903.

8 Fenwick PK, Aggett PJ, MacDonald D, Huber $\mathrm{C}$, Wakelin D: Zinc deficiency and zinc repletion: Effect on the response of rats infection with Trichinella spiralis. Am J Clin Nutr 1990; 52:166-172.
9 Gishan F: Transport of electrolytes, water and glucose in zinc deficiency. J Pediatr Gastroenterol Nutr 1984;3:608-612.

10 Schlesinger L, Averalo M, Arredondo S, Diaz M, Lonnerdal B, Stekel A: Effect of zinc-fortified formula on immunocompetence and growth of malnourished infants. Am J Clin Nutr 1992;56:491-498.

11 Sazawal S, Black RE, Bhan MK, Bhandari N, Sinha A, Jalla S: Zinc sulfate supplementation in young children with acute diarrhea in India. N Engl J Med 1995;333:839-844.

12 Bettger WJ, O’Dell BL: A critical physiological role of zinc sulfate in the structure and function of biomembranes. Life Sci 1981;28:14251438. 